[Agr. Biol. Chem., Vol. 34, No. 12, p. 1815 1820, 1970]

\title{
Dissociation into Subunits of a 7S Protein in Soybean Globulins with Urea and Sodium Dodecyl Sulfate
}

\author{
By Ikunori Koshiyama \\ Noda Institute for Scientific Research, Noda-shi, Chiba-ken, Japan \\ Received May 13, 1970
}

\begin{abstract}
A $7 S$ protein isolated from soybean globulins was dissociated into a similar slowsedimenting material (subunit) by the treatment of urea and sodium dodecyl sulfate (SDS).

Sedimentation coefficients of the subunits obtained by treating with $8 \mathrm{M}$ urea and $0.25 \%$ SDS were $1.35 \mathrm{~S}$ and $2.00 \mathrm{~S}$, and molecular weights were 22,500 and 34,000 , respectively. These subunits by the both treatments were apparently different in conformation from the results of optical rotatory dispersion, i.e., urea treatment caused the almost complete unfolding of the subunit structure. On the contrary, SDS treatment contributed new partial formation of a $\alpha$-helical conformation for the subunits.

These dissociations were extremely disturbed by the presence of sodium chloride.
\end{abstract}

There was a possibility that a $7 \mathrm{~S}$ protein in soybean globulins" had a multi-subunit structure from N-terminal analysis. ${ }^{21}$ On the other hand, recently, the $11 \mathrm{~S}$ protein which was an another major component of soybean globulins was clarified to have twelve polypeptide chains (subunits), eight of which end in glycine, two in phenylalanine and two in either leucine or isoleucine. ${ }^{31}$

In general, urea and an anionic detergent, sodium dodecyl sulfate (SDS), was often used to dissociate the proteins into the subunits. Though the final objective of this study is to isolate the individual subunits of which the $7 \mathrm{~S}$ protein is made up and to make the subunit structure clear, this paper deals with the dissociation of the protein by two treatments with urea and the detergent, and subsequently, those subunits obtained by the both treatments

* This work contributes Part $\mathrm{X}$ of Studies on Soybean Proteins. Presented at the Annual Meeting of the Agricultural Chemical Society of Japan, Tokyo, April 2nd, 1969.

1) I. Koshiyama, Agr. Biol. Chem., 29, 885 (1965).

2) I. Koshiyama, Cereal Chem., 45, 394 (1968).

3) N. Catsimpoolas, D. A. Rogers, S. J. Circle and E. W. Neyer, ibid., 44, 631 (1967). are physico-chemically compared using sedimentation and optical rotatory dispersion.

\section{MATERIALS AND METHODS}

Protein sample. According to the method described in a previous paper, ${ }^{11}$ the $7 \mathrm{~S}$ protein was prepared. This $7 \mathrm{~S}$ protein is called $\gamma$-conglycinin by Catsimpoolas. ${ }^{4}-6$ !

Ultracentrifugation. Sedimentation analysis was performed with a Hitachi UCA-1 centrifuge at $55,430 \mathrm{rpm}$ in the $0.5 \mu$ standard buffer $(0.0325 \mathrm{M}$ $\mathrm{K}_{2} \mathrm{HPO}_{4}, 0.0026 \mathrm{M} \mathrm{KH}_{2} \mathrm{PO}_{4}, 0.4 \mathrm{M} \mathrm{NaCl}, \mathrm{pH} 7.60^{7 \prime}$ ) and $0.01 \mathrm{M}$ tris-hydrochloric acid buffer, $\mathrm{pH} 8.20$, and $51,200 \mathrm{rpm}$ in $0.01 \mathrm{~N}$ hydrochloric acid. Routine assay runs were made at $20^{\circ} \mathrm{C}$ and protein concentration was $0.70 \%$.

Molecular weight. Molecular weights were determined by the short column method of Yphantis ${ }^{81}$

4) N. Catsimpoolas, E. Leuthner and E. W. Meyer, Arch. Biochem. Biophys., 127, 338 (1968).

5) N. Catsimpoolas and C. Ekenstam, ibid,, 129, 490 (1969).

6) N. Catsimpoolas, Cereal Chem., 46, 369 (1969).

7) W.J. Wolf and D. R. Briggs, Arch. Biochem. Biophys., 85, 186 (1959).

8) D. A. Yphantis, Ann. N.Y. Acad. Sci., 88, 586 (1960). 
using a eight channel cell.

Optical rotatory dispersion measurements. Optical rotatory dispersion was measured with a Japan Spectroscopic model ORD/UV-5 recording spectropolarimeter (double prism, double monochrometer) employing a xenon arc lamp as the source of radiation. Measurements were made at a room temperature near $20^{\circ} \mathrm{C}$. For the measurements, in the visible and nearultraviolet region $(300 \sim 600 \mathrm{~m} \mu), 100 \mathrm{~mm}$ cylindrical cell was used with the protein concentration of $0.35 \%$ to $0.45 \%$.

The resulting data were interpreted by the MoffitYoung equation, 9,101

$$
\begin{aligned}
{\left[m^{\prime}\right] \lambda } & =3 /\left(n^{2}+2\right) \cdot M_{0} / 100 \cdot[\alpha]_{\lambda}, \\
& =\lambda_{0}^{2} /\left(\lambda^{2}-\lambda_{0}^{2}\right) \cdot a_{0}+\lambda_{0}^{4} /\left(\lambda^{2}-\lambda_{0}^{2}\right)^{2} \cdot b_{0}
\end{aligned}
$$

and the one-term Drude equation, 9,101

$$
[\alpha]_{\lambda}=A /\left(\lambda^{2}-\lambda_{c}{ }^{2}\right)
$$

In the equation (1), $\left[\mathrm{m}^{\prime}\right] \lambda$ is the reduced mean residue rotation of the polypeptide at the wave-length of $\lambda, n$ is the refractive index of solvent, $\lambda_{0}$ is the absorption wave-length asssociated with the rotation assumed to be $212 \mathrm{~m} \mu$, and $M_{0}$ is the mean residue weight.

The refractive index value $(n)$ was measured with an Abbe refractometer, and the dispersion of refractive index was neglected. As the mean molecular weight of residues $\left(M_{0}\right)$, the value of 107.4 was employed based on the data previously reported. ${ }^{2)}$

The parameters, $a_{0}$ and $b_{0}$, were evaluated from the intercept and slope, respectively, of a plot of $\left[m^{\prime}\right] \lambda \cdot\left(\lambda^{2}-\lambda_{0}^{2}\right)$ versus $1\left(\lambda^{2}-\lambda_{0}^{2}\right)$. The dispersion constant $\lambda_{c}$ in the equation (2) was similarly obtained from the slope of a plot of $[\alpha]_{\lambda} \cdot \lambda^{2}$ versus $[\alpha]_{\lambda}$.

For the measurement in the ultraviolet region $(200 \sim 250 \mathrm{~m} \mu), 1.0 \mathrm{~mm}$ cell was employed. The protein concentration was $0.15 \%$ to $0.25 \%$.

\section{RESULTS}

Sedimentation behavior of the $7 S$ protein in the presence of $S D S$

When the $7 \mathrm{~S}$ protein was overnight treated with $0.25 \%$ SDS $\left(8.68 \times 10^{-3} \mathrm{M}\right)$ in $0.01 \mathrm{M}$ trishydrochloric acid buffer of $\mathrm{pH} 8.20$, it was converted to a slow-sedimenting component having a sedimentation constant of $1.91 \mathrm{~S}$ (Fig. 1, A). Treating with a lower concentration of the detergent $(0.025 \%)$ gave two peaks $(10.29 \mathrm{~S}$ and $2.02 \mathrm{~s})$ in the sedimentation pattern as shown in Fig. 1, B, but these two peaks changed to a single slow-sedimenting form $(1.83 \mathrm{~S})$ by the long time treatment (Fig. 1, C).

Dissociation to subunits of the $7 \mathrm{~S}$ protein

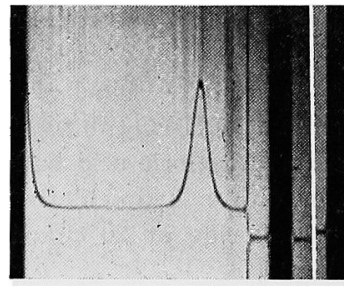

A

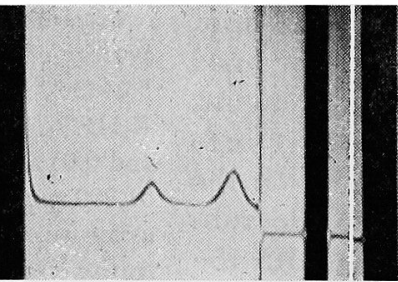

B

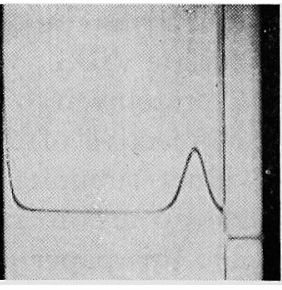

C

FIG. 1. Ultracentrifugal Patterns of the $7 \mathrm{~S}$ Protein in the Presence of SDS.

A: $0.25 \%$ SDS.

B: $0.025 \circ ;$ SDS.

C: $0.025 \%$ SDS. Prolonged treatment during 11 days.

Photographs were taken after 100 min of sedimentation for $\mathrm{A}, 41 \mathrm{~min}$ for $\mathrm{B}$ and $60 \mathrm{~min}$ for $\mathrm{C}$.

9) P. Urnes and P. Doty, "Advances in Protein Chemistry," Vol. 16, ed. by C. B. Anfinsen, Jr., Academic Press, New York, 1961, p. 401.
10) G. D. Fasman, "Method in Enzymology," Vol 6, ed. by S. P. Colowick and N. O. Kaplan, Academi Press, New York, 1963, p. 928. 


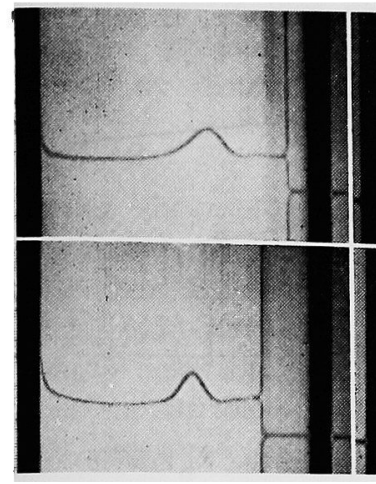

A

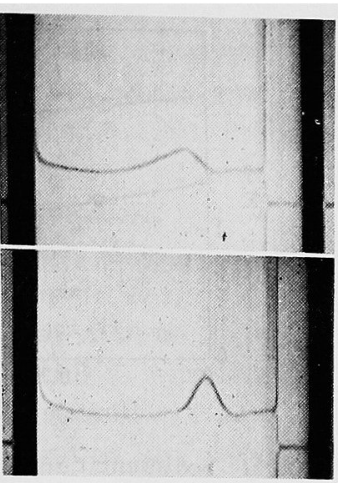

B
FIG. 2. Effect of Ionic Strength $(0.5 \mu)$ in the Presence of SDS on Stability of Ultracentrifugal Patterns of the 7S Protein.

A: $0.025 \%$, SDS (upper). Dialysed against the $0.5 \mu$ standard buffer for 3 days (bottom).

B: $0.25 \%$ SDS (upper). Dialysed against the $0.5 \mu$ standard buffer for 3 days (bottom).

Photographs were taken after $40 \mathrm{~min}$ of sedimentation.

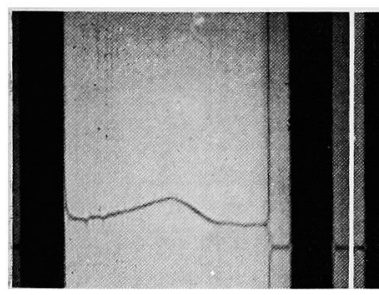

A

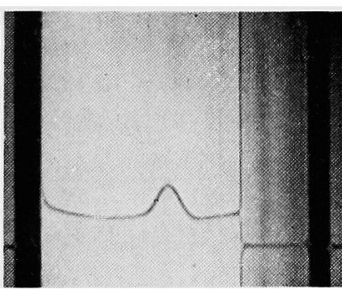

B
FIG. 3. Ultracentrifugal Patterns of the 7S Protein in $0.01 \mathrm{~N} \mathrm{HCl}$ Containing $0.025 \%$ SDS (A), and $0.025 \%$ SDS and $0.1 \mathrm{M} \mathrm{NaCl}$.

Photographs were taken after $40 \mathrm{~min}$ of sedimentation at $51,200 \mathrm{rpm}$.

with SDS was extremely disturbed in the presence of sodium chloride. As shown in the upper row of Fig. 2, B, conversion of the protein to the slow-sedimenting form was not observed even by the overnight treatment with $0.25 \%$ solution of the detergent containing $0.5 \mathrm{M}$ sodium chloride. Rather, nonspecific association was observed in the sedimentation pattern. The protein treated with SDS in the presence of sodium chloride easily restored a sedimentation peak of $7 \mathrm{~S}$ by dialysis against the $0.5 \mu$ standard buffer overnight as shown in the lower row of Fig. 2. But, the protein treated with the detergent without sodium chloride precipitated in the $0.5 \mu$ standard buffer.

In $0.01 \mathrm{~N}$ hydrochloric acid, the $7 \mathrm{~S}$ protein precipitated by the treatment with $0.25 \%$ SDS, and associated non-specifically in $0.025 \%$ solution of the detergent as shown in Fig. 3, A. Similar effect of sodium chloride in the treatmet with SDS on sedimentation pattern was also observed in the acidic solution of $0.01 \mathrm{~N}$ hydrochloric acid as well as in the alkaline solution of $\mathrm{pH} 8.20$. Figure 3, B shows the results of the presence of $0.1 \mathrm{M}$ sodium chloride.

\section{Dissociation to subunits of the $7 S$ protein with urea}

Results of urea treatment to the $7 \mathrm{~S}$ protein were shown in Fig. 4, i.e., the sedimentation coefficients $\left(s_{20, \mathrm{w}}\right)$ of the protein diminished following the curve $\mathrm{A}$ in Fig. 4 with the increase of urea concentration. However, by the presence of $0.5 \mathrm{M}$ sodium chloride, dissociation of the protein with urea, especially in lower concentration of urea, was extremely interfered as shown in Fig. 4, $\mathrm{B}_{1}$.

In this experiment, to dissociate the protein into subunits having sedimentation coefficients lower than $2 \mathrm{~S}$, at least $5 \mathrm{M}$ urea needed in the absence of sodium chloride and more than $6 \mathrm{M}$ urea in the presence of it.

Most part of the $7 \mathrm{~S}$ protein treated with various concentrations of urea in the presence of $0.5 \mathrm{M}$ sodium chloride easily restored a sedimentation pattern of $7 \mathrm{~S}$ as shown in Fig. $4, \mathrm{~B}_{2}$ by dialysis against the $0.5 \mu$ standard buffer, though non-specific aggregation somewhat occurred in the small part of the protein with the increase of urea concentration. But, the phenomena were not observed in the protein treated with urea in the absence of sodium chloride.

On the other hand, it was easily observed that the protein dissociated into subunits 


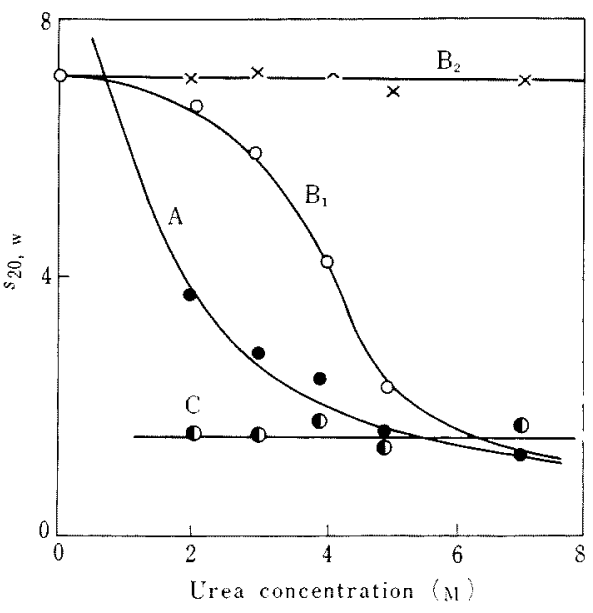

FIG. 4. Correlation of Sedimentation Constant of the $7 \mathrm{~S}$ Protein and Urea Concentration.

A: Treated in $0.01 \mathrm{M}$ Tris-HCl buffer, $\mathrm{pH} 8.20$.

$\mathrm{B}_{1}$ : Treated in the buffer containing $0.5 \mathrm{M}$ $\mathrm{NaCl}$.

$\mathrm{B}_{2}$ : Dialysed $\mathrm{B}_{1}$ against the $0.5 / \%$ standard buffer for 2 days.

C: Treated in $0.01 \mathrm{~N} \mathrm{HCl}$

smaller than $2 \mathrm{~S}$ in $0.01 \mathrm{~N}$ hydrochloric acid, even in $2 \mathrm{M}$ urea.

From the results obtained above, it can be said that both urea and SDS have an ability to dissociate the $7 \mathrm{~S}$ protein into subunits having a similar sedimentation coefficient.

\section{Comparison of the subunits obtained by the treat-} ments of SDS and urea

From the results of this experiment, the subunits obtained by treating with SDS was similar to those with urea, ultracentrifugally in appearance. However, it is a question whether these subunits are completely the same or not. Accordingly, it is necessary to compare these subunits physico-chemically.

\section{Ultracentrifugal properties}

1. Sedimentation coefficient. Figure 5 shows the relationship between sedimentation coefficients and protein concentration for each series of dilutions, i.e., the values of $s_{20, w}^{\circ}$ with

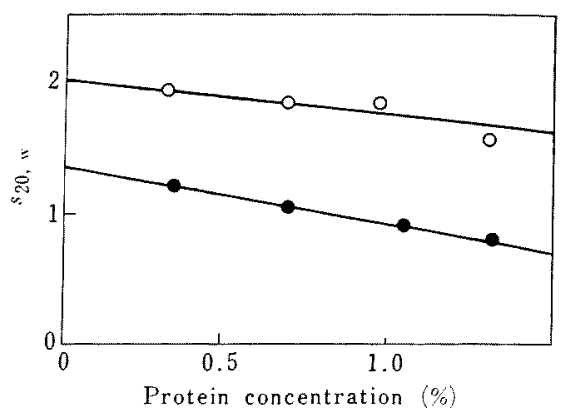

FIG. 5. Sedimentation Rate of the $7 S$ Protein as a Function of Concentration in $8 \mathrm{M}$ Urea and $0.25 \%$ SDS.

- in $8 \mathrm{M}$ urea

$\mathrm{O}-\mathrm{O}:$ in $0.25 \%$ SDS

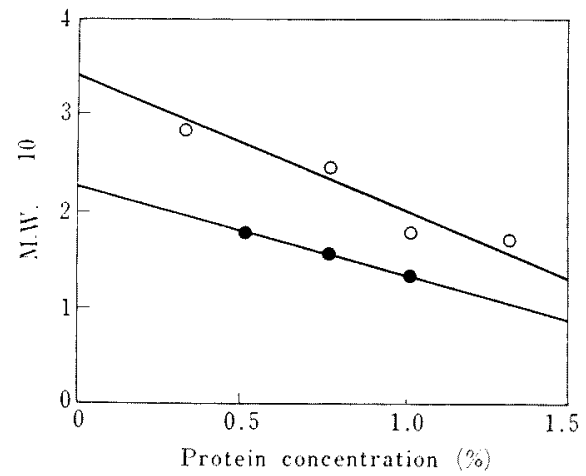

FIG. 6. Molecular Weight of the 7S Protein by the Yphantis' Method as a Function in $8 \mathrm{M}$ Urea and $0.25 \%$ SDS.

- - in $8 \mathrm{M}$ urea

$\mathrm{O}-\mathrm{O}:$ in $0.25 \%$ SDS

$0.25 \%$ SDS and $8 \mathrm{M}$ urea were $2.00 \mathrm{~S}$ and $1.35 \mathrm{~S}$, respectively.

2. Molecular weight. The weight average molecular weights of the subunits obtained by two treatments were plotted in Fig. 6 as a function of protein concentration, assuming the partial specific volume of $0.725 \mathrm{ml} / \mathrm{g}$. The molecular weights obtained by extrapolation to infinite dilution were 34,000 for SDS treatment and 22,500 for urea treatment, respectively. 
Therefore, it was considered that the dissociation products with two reagents were apparently different in molecular size each other.

\section{Optical rotatory dispersion properties}

An each optical rotatory dispersion of the $7 \mathrm{~S}$ protein under three conditions, i.e., in the $0.5 \mu$ standard buffer, in $0.01 \mathrm{M}$ tris-hydrochloric acid buffer of $\mathrm{pH} 8.20$ containing $8 \mathrm{M}$ urea and in the buffer containing $0.25 \%$ SDS, was measured in the visible and near-ultraviolet regions $(300 \sim 600 \mathrm{~m} \mu)$. The results were shown in Table I.

According to Table I, a more larger change in the specific rotation, $[\alpha]_{\mathrm{D}}$, and $a_{0}$ value to the negative direction occurred upon the treatment of urea than that of SDS. On the other hand, the $b_{0}$ value, which can be used as measure of a helix content of protein, changed from -38 to -74 with $0.25 \%$ SDS and to zero with $8 \mathrm{M}$ urea, respectively. These results seemed to indicate that the treatment with $8 \mathrm{M}$ urea caused the almost complete unfolding of the protein as a whole. On the contrary, the treatment with $0.25 \%$ SDS may be said from $a_{0}$ and $b_{0}$ values not only to cause the incomplete unfolding of the protein, but also to contribute new partial formation of a helical conformation.

The changes in the $\alpha$-helix content from $-b_{0}$ value by both treatments with $8 \mathrm{~m}$ urea and $0.25 \%$ SDS can be confirmed by changes

Table I. Optical Rotatory Dispersion DATA OF THE 7S PROTEIN

\begin{tabular}{lccc} 
Parameters & Native $^{a)}$ & $\begin{array}{c}8 \text { M urea }^{b} \\
\text { treatment }^{\prime}\end{array}$ & $\begin{array}{c}0.25 \% \text { SDS }^{b} \\
\text { treatment }^{-}\end{array}$ \\
\hline$[\alpha]_{\mathrm{D}}$ & -44.1 & -109.3 & -71.9 \\
$a_{0}$ & -246 & -600 & -371 \\
$b_{0}$ & -38 & 0 & -74 \\
$\lambda_{c}(\mathrm{~m} \mu)$ & 226 & 216 & 227 \\
{$\left[\mathrm{M}^{\prime}\right]_{233}$} & -1890 & - & -3740
\end{tabular}

a) Dissolved in the $0.5 \mu$ standard buffer.

b) Treated with $0.01 \mathrm{M}$ tris-hydrochloric acid buffer of $\mathrm{pH} 8.20$ containing urea or SDS.

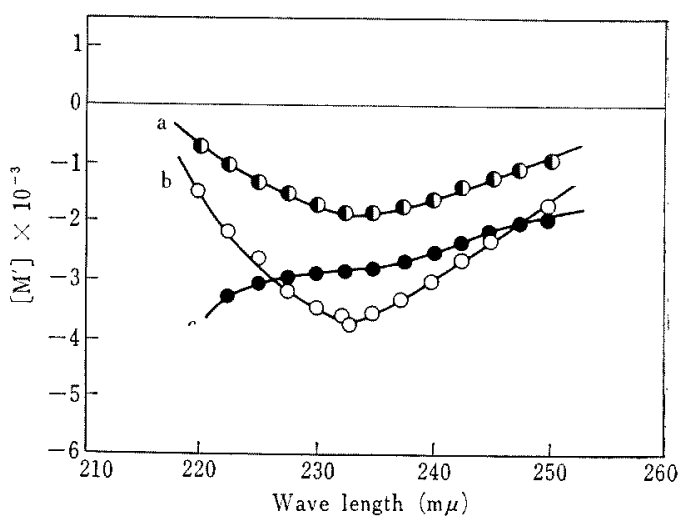

FIG. 7. Mean Residue Rotation of the $7 \mathrm{~S}$ Protein as a Function of Wave Length.

a: dissolved in the $0.5 \mu$ standard buffer.

b: treated with $0.25 \%$ SDS.

c: treated with $8 \mathrm{M}$ urea.

in the magnitude of the trough at the critical wave length of $233 \mathrm{~m} \mu$. As shown in Fig. 7 and the last column of Table I $\left(\left[\mathrm{m}^{\prime}\right]_{233}\right)$, in $8 \mathrm{M}$ urea solution the trough at $233 \mathrm{~m} \mu$ completely disappeared. However, the amplitude of negative Cotton effect at $233 \mathrm{~m} \mu$ in $0.25 \%$ SDS solution increased about two times as large as that of the negative protein.

From the results of sedimentation and optical rotatory dispersion, it might be concluded that the subunits obtained by the both treatments were surely different in molecular size and conformation each other. However, there was a full possibility that the subunits obtained by treating with SDS made the complexes with the detergent, and consequently the molecular size was larger than that of them obtained with urea. Therefore, it could not be concluded within the limits of this experiment whether the subunits were essentially different or not.

\section{DISCUSSION}

It had been observed that there were new formation of a partial $\alpha$-helical conformation by treating with SDS in many proteins, i.e., 
chymotrypsinogen A, trypsin, soybean trypsin inhibitor, histones ${ }^{11}$ and aspergillopeptidase $\mathrm{A}^{121}$ as well as in this protein. Moreover, recently, it was reported that the apparent micellar molecular weights of the protein-SDS complexes, such as thyroglobulin, ovalbumin, ovomucoid, lysozyme, bovine $\gamma$-globulin and Tamm \& Horsfall urinary glycoprotein, approximately the same $(34,000 \sim 41,000)$ irrespective of the molecular weight of the protein to which they were attached. Therefore, it may be said thut the results from this experiment give a new example for the proteins mentioned above.

Fukushima ${ }^{14}$ supposed that $\alpha$-helix content of the native $7 \mathrm{~S}$ protein was very low, because the $-b_{0}$ value of it was $5^{\circ}$ In this experiment, the $-b_{0}$ value of the native protein was $38^{\circ}$ as shown in Table I. From the content of $\alpha$-helix was estimated to be about $6 \%$ (for $100 \%$ right-handed $\alpha$-helix, $b_{0}=-630$ ).

11) B. Jirgensons, J. Biol. Chem., 241, 4855 (1966).

12) E. Ichishima and F. Yoshida, Biochem. Biophys. Acta, 147, 341 (1967).

13) R. Pitt-Rivers and F.S. A. Impiombato, Biochem. J., 109, 825 (1968).

14) D. Fukushima, Cereal Chem., 45, 203 (1968).
In any case, the native $7 \mathrm{~S}$ protein is considered to have a very low $\alpha$-helix content.

The molecular weight obtained by treating with $8 \mathrm{M}$ urea was about one nineth of the parent molecule. The results agreed almost to the numbers of subunits obtained by $\mathrm{N}$ terminal amino acid analysis. ${ }^{21}$

The action of stabilization to the gross structure of the $7 \mathrm{~S}$ protein by addition of sodium chloride in the treatments of urea and SDS was also recognized in that of acid. ${ }^{151}$ The reason cannot be discussed within the limits of this experiment, but it is a very interesting subject for a future study.

Acknowledgement. The author expresses his sincerest thanks to Prof. M. Fujimaki of the University of Tokyo and Prof. Y. Sakurai of the Japan Women's University for their kind guidance and encouragement throughout this work. Great indebtedness is acknowledged to Prof. K. Arima and Prof. Y. Ikeda of the University of Tokyo, Mr. K. Hayashi for their valuable discussions and suggestions. Thanks are due to Dr. M. Mogi and Dr. N. Iguchi for their encouragement; and to Miss. T. Ichikawa for her technical assistance.

15) I. Koshiyama, Agr. Biol. Chem., 32, 879 (1968). 